\title{
A Late Miocene potential neobalaenine mandible from Argentina sheds light on the origins of the living pygmy right whale
}

\author{
Mónica R. Buono, Maria T. Dozo, Felix G. Marx, and R. Ewan Fordyce \\ Acta Palaeontologica Polonica 59 (4), 2014: 787-793 doi: http://dx.doi.org/10.4202/app.2012.0122
}

The origins and evolutionary relationships of the pygmy right whale (Caperea marginata), the only living member of the Neobalaeninae, have been the subject of a long-standing debate. This phylogenetic uncertainty is compounded by a limited neobalaenine fossil record. Here, we report a Late Miocene mysticete mandible from Patagonia, Argentina, and provisionally refer it to Neobalaeninae, gen. et sp. indet. The new material represents only the third report of a fossil neobalaenine, and the first fossil occurrence of this lineage in the southwestern Atlantic. It is also the oldest specimen so far reported, thus corroborating the idea of an early divergence time for neobalaenines.

Mónica R. Buono [buono@cenpat.edu.ar ]and Maria 240 T. Dozo [dozo@cenpat.edu.ar ], Laboratorio de Paleontología, Centro Nacional Patagónico, CONICET, 9120

Puerto Madryn, Chubut, Argentina; Felix Marx [felix.marx@otago.ac.nz], Department of Geology, University of Otago, PO Box 56, Dunedin 9054, New Zealand; current address: Department of Geology and Palaeontology, National Museum of Nature and Science, 4-1-1 Amakubo, Tsukuba 305-0005, Japan; and R. Ewan Fordyce [ewan.fordyce@ otago.ac.nz], Department of Geology, University of Otago, PO Box 56, Dunedin 9054, New Zealand.

This is an open-access article distributed under the terms of the Creative Commons Attribution License (for details please see creativecommons.org), which permits unrestricted use, distribution, and reproduction in any medium, provided the original author and source are credited. 
